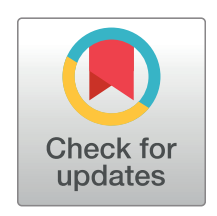

CORRECTION

\title{
Correction: Social determinants of food group consumption based on Mediterranean diet pyramid: A cross-sectional study of university students
}

\author{
Roberto Martinez-Lacoba, Isabel Pardo-Garcia, Elisa Amo-Saus, Francisco Escribano- \\ Sotos
}

The ORCID iDs are missing for the second, third, and fourth authors. Please see the authors' respective ORCID iDs here:

Author Isabel Pardo-Garcia’s ORCID iD is: 0000-0003-4391-6011 (https://orcid.org/00000003-4391-6011).

Author Elisa Amo-Saus's ORCID iD is: 0000-0002-2100-9325 (https://orcid.org/00000002-2100-9325).

Author Francisco Escribano-Sotos's ORCID iD is: 0000-0002-2747-6725 (https://orcid.org/ 0000-0002-2747-6725).

\section{Reference}

1. Martinez-Lacoba R, Pardo-Garcia I, Amo-Saus E, Escribano-Sotos F (2020) Social determinants of food group consumption based on Mediterranean diet pyramid: A cross-sectional study of university students. PLoS ONE 15(1): e0227620. https://doi.org/10.1371/journal.pone.0227620 PMID: 31999722

\section{G openaccess}

Citation: Martinez-Lacoba R, Pardo-Garcia I, AmoSaus E, Escribano-Sotos F (2020) Correction: Social determinants of food group consumption based on Mediterranean diet pyramid: A crosssectional study of university students. PLOS ONE 15(8): e0238270. https://doi.org/10.1371/journal. pone. 0238270

Published: August 21, 2020

Copyright: ๑ 2020 Martinez-Lacoba et al. This is an open access article distributed under the terms of the Creative Commons Attribution License, which permits unrestricted use, distribution, and reproduction in any medium, provided the original author and source are credited. 